Article

\title{
Oxidized and Non-Oxidized Multiwalled Carbon Nanotubes as Materials for Adsorption of Lanthanum(III) Aqueous Solutions
}

\author{
Francisco J. Alguacil@, Irene García-Díaz, Esther Escudero Baquero, Olga Rodríguez Largo and \\ Félix A. López *(1) \\ National Center for Metallurgical Research (CENIM), Spanish National Research Council (CSIC), \\ Avda. Gregorio del Amo 8, 28040 Madrid, Spain; fjalgua@cenim.csic.es (F.J.A.); irenegd@cenim.csic.es (I.G.-D.); \\ mebaquero@cenim.csic.es (E.E.B.); olga.rodriguez@csic.es (O.R.L.) \\ * Correspondence: f.lopez@csic.es or flopez@cenim.csic.es; Tel.: +34-91-553-89-00
}

Received: 18 May 2020; Accepted: 6 June 2020; Published: 8 June 2020

check for updates

\begin{abstract}
The behavior of oxidized and non-oxidized multiwalled carbon nanotubes (MWCNTs) in the adsorption of lanthanum(III) from aqueous solutions is described. Metal uptake is studied as a function of several variables such as the stirring speed of the system, $\mathrm{pH}$ of the aqueous solution and metal and nanomaterial concentrations. The experimental results are fitted to various kinetic and isotherm models, the rate law being fitted to the film diffusion and particle diffusion models, when the non-oxidized and the oxidized nanomaterials are used to remove lanthanum from the solution, respectively. Sulfuric acid solutions seem to be appropriate to recover the metal from La-loaded nanomaterials.
\end{abstract}

Keywords: lanthanum; multiwalled carbon nanotubes; adsorption; recovery

\section{Introduction}

Since the 1960s, the applications of rare earths in daily life have increased until they have come to be elements which are critical in industrial developments and modern technologies, thus in this context, these elements are designated as technology-critical elements [1]. Although rare earths are more abundant than precious metals, their individual extraction is not an easy task for two main reasons; (i) they are dispersed in ores, and (ii) having similar chemical properties, it is difficult to separate them.

Rare earths (REs) are widely used in different sectors such as clean energy, nuclear energy, chemical engineering, consumer electronics, advanced transportation, agriculture, communication, metallurgy and medicine [2,3]. Currently, the REs importance are also increasing due to their use in green carbon technologies, such as rechargeable car batteries, electronic devices, permanent magnets, wind turbines and so on [4].

They are considered by the European Commission as the most critical raw materials group with the highest supply risk [5]. However, in spite of their great applications and the large amounts of RE-waste, their recycling is still poorly developed, i.e., in the EU only $6 \%$ of the heavy REs and 7\% of the light REs are recovered [6,7].

Among these elements, lanthanum is used in fields such as ceramics, metal alloys, batteries, glass, semiconductors, catalysts, magnetic materials and rechargeable lithium-nickel batteries $[8,9]$ and it is being considered as one of the most critical elements until 2025 [4]. These industrial sectors generate La wastewater together with mining, radioactive waste and the recycling of RE-waste. Particularly, the recycling of electric and hybrid vehicles batteries is a great social and technological 
challenge, mainly due to the environmental problems associated with their dangerous compounds, heavy metals and the recovery of valuable metals, particularly REs, cerium, lanthanum, neodymium and praseodymium which form part of the anode in the nickel-metal hydride (Ni-MH) cell $[6,10]$, one of the most used [11,12]. Spent Ni-MH batteries contain $36-42 \% \mathrm{Ni}, 3-4 \%$ Co and $8-10 \%$ mixed metals consisting of $\mathrm{La}, \mathrm{Ce}, \mathrm{Pr}$ and $\mathrm{Nd}$ [9]. The rare earth elements (REE) within these batteries could potentially be recycled using hydrometallurgical or pyrometallurgical recycling processes, although these processes are still under research [7]. It is estimated that one third of the REE in a typical waste electrical and electronic equipment (WEEE) waste stream could be manually sorted via the removal of batteries [13]. More recently, other ways to recover REE from batteries have been developed, such as, the use of multifunctional Diphonix resin [11], or via antisolvent precipitation [10]. However, the most used processes still are the chemical ones. The complexity of the treatments and the number of operations are a function of the metals that can be recovered [12]. Including separation technologies, adsorption is one of the most popular methodologies due to its simplicity, flexibility, low cost and high efficiency [14]. In the last decades, the study and the development of new adsorbent methods have been constant, such as clay ore, chelating, carbon nanomaterials, metal organic frameworks (MOFs), halloysite nanotubes and activated carbon [15-22]. Among these, carbon nanomaterials are a great research field due to their metals adsorption properties [10,23-28].

Various research has been conducted into La adsorption. Crane et al. [29] studied the behavior of REs and La adsorption onto nanoscale zero valent iron (nZVI) particles in an acid mine drainage medium and different synthetic solutions, the La removal capacity of nZVI was $61.0 \mathrm{mg} / \mathrm{g}$ and $410 \mathrm{mg} / \mathrm{g}$ of $\mathrm{Yb}$ in a solution with an initial concentration of $1000 \mathrm{mg} / \mathrm{L} \mathrm{LaCl}_{3}$ and $\mathrm{YbCl}_{3}$; Zhao et al. [30] reported the recovery of $\mathrm{La}(\mathrm{III})$ ions from leachates of bauxite residue with a polyethylenimine (PEI) modified chitosan adsorbent. PEI addition gives the adsorbent material an excellent buffering capacity at extremely acidic $\mathrm{pH}$, one characteristic of bauxite leachates. This material reaches a separation $\mathrm{La}(\mathrm{III})-\mathrm{Al}(\mathrm{III})$ factor of 3:1. Kolodynska et al. [8] confirmed that $\mathrm{Nd}(\mathrm{III}), \mathrm{Ce}(\mathrm{III})$ and $\mathrm{La}(\mathrm{III})$ in acid nitric solutions leaching from spent Ni-MH cells preferred to bind with ligands that have oxygen as a donor atom such as Amberlita 200C Na and Amberlita 200C $\mathrm{H}$ and presented high sorption efficiency, whereas Dowx M 4195 showed low adsorption capacity. Iftekhar et al. [31] reviewed the effect of different parameters that affect La adsorption in various adsorbents, biosorbents, inorganic nano/composites, magnetic, silica, graphene oxides, activated carbon, etc., the article concluded that the adsorbent, mainly hybrid composites materials, which present carboxyl, hydroxyl and amine groups, showed a higher La removal efficiency over a wide $\mathrm{pH}$ range with a higher adsorption capacity compared with other adsorbents such as magnetic adsorbents and bioadsorbents. Graphene-based magnetic nanocomposites with high selectivity in the adsorption of lanthanum were synthesized by Alparslna et al. [32]. The efficiency in La adsorption was $93 \%$ in optimum conditions ( $\mathrm{pH} 4.0$ and $0.01 \mathrm{~g}$ of sorbent at 15 $\mathrm{min}$ ), however the desorption in the studied conditions was practically negligible. Graphitic carbon nitride presented excellent adsorption properties of $\mathrm{Eu}(\mathrm{III}), \mathrm{La}(\mathrm{III}), \mathrm{Nd}(\mathrm{III})$ and $\mathrm{Th}(\mathrm{IV})$ the maximum adsorption capacities respectively were 155.0, 122.3, 132.5 and $185.6 \mathrm{mg} / \mathrm{g}$ [33]. Finally, Cardoso et al. [34] also presented a deep review about the adsorption capacity of different kinds of carbon nanomaterials.

Since the global demand of REs is increasing and it is expected to experience a notable growth over time [3], the present investigation concerns the adsorption of lanthanum(III) from aqueous solutions with two commercially available adsorbents, in the form of non-oxidized and oxidized (carboxylic groups) multiwalled carbon nanotubes.

\section{Materials and Methods}

The adsorbents used in this research (Merk KGaA, Damstadt, Germany) have the characteristics shown in Table 1. 
Table 1. Characteristics of the adsorbents.

\begin{tabular}{lccccccc}
\hline Adsorbent & $\begin{array}{c}\text { Purity } \\
\mathbf{( \% )}\end{array}$ & $\begin{array}{c}\text { a Functionalization } \\
\text { Grade }(\mathbf{\%})\end{array}$ & $\begin{array}{c}\text { BET } \\
\left(\mathbf{m}^{\mathbf{2}} \mathbf{/ g}\right)\end{array}$ & $\begin{array}{c}\text { Average } \\
\text { Diameter }(\mathbf{n m})\end{array}$ & Density & $\begin{array}{c}\text { Length } \\
(\boldsymbol{\mu} \mathbf{m})\end{array}$ & $\begin{array}{c}\text { Method of } \\
\text { Process }\end{array}$ \\
\hline MWCNT & $>98 \%$ & - & 263 & $6-9$ & 2.1 & 5 & CVD \\
ox-MWCNT & $>80 \%$ & $>8$ & 307 & 9.5 & - & 1.5 & CVD \\
\hline
\end{tabular}

${ }^{\text {a }}$ carboxylic groups; CVD: chemical vapour deposition.

On both adsorbents, the zeta potential was measured using a Zetasizer Malvern Nano ZS (Malvern, UK) at $25^{\circ} \mathrm{C}$. Aqueous suspensions were prepared at $\mathrm{pH}$ values between 1 and 13 using solutions of $\mathrm{HCl}$ and $\mathrm{NaOH}$, while the carbon dosage was adjusted to $0.1 \mathrm{~g} \mathrm{~L}^{-1}$. The suspensions were dispersed with a Bandelin Electronic Sonopuls HD 3100 sonicator (Bandelin, Berlín, Germany), using amplitudes of $60 \%$ for $150 \mathrm{~s}$. The results from these measurements are shown in Figure 1, indicating that the isoelectronic points (IEP) were 1.22 and 0.26 for the multiwalled carbon nanotubes (MWCNTs) and ox-MWCNTs, respectively.

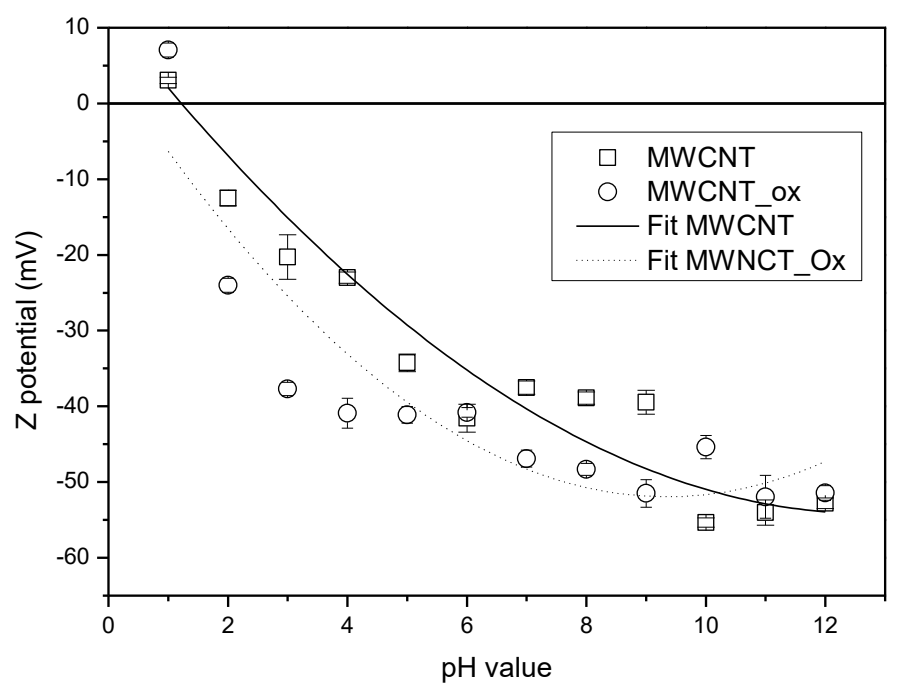

Figure 1. Zeta potential vs. $\mathrm{pH}$.

Lanthanum(III) nitrate $\left(\mathrm{La}\left(\mathrm{NO}_{3}\right)_{3} \cdot 6 \mathrm{H}_{2} \mathrm{O}\right)$ (Merk KGaA, Darmstadt, Germany) was used as the source for $\mathrm{La}^{3+}$ ions. Other reagents were of AR grade.

Batch adsorption experiments were performed in a $0.5 \mathrm{~L}$ glass reactor providing mechanical shaking, and the percentage of metal in the solution was determined by monitoring the metal concentration by inductively coupled plasma atomic emission spectroscopy (ICP-OES) using Agilent 5100 (Agilent Technologies, Santa Clara, CA, USA) in the aqueous solution as a function of time:

$$
\%=\frac{[L a]_{a q, t}}{[L a]_{a q, 0}} \cdot 100
$$

where the percentage of metal adsorption, onto the corresponding adsorbent, was calculated by the mass balance (Equation (1)). Desorption experiments were carried out on the same basis.

\section{Results}

\subsection{La(III) Uptake by Non-Oxidized Multiwalled Carbon Nanotubes (MWCNTs)}

Having non-active groups, lanthanum uptake onto the present nanomaterial can be described by the next equilibrium:

$$
\mathrm{La}_{\mathrm{aq}}^{3+} \Leftrightarrow \mathrm{La}_{\mathrm{c}}^{3+}
$$


where $\mathrm{La}_{\mathrm{aq}}{ }^{3+}$ and $\mathrm{La}_{\mathrm{c}}{ }^{3+}$ represented the lanthanum ions in the aqueous solution and occupying the corresponding adsorptive sites in the carbon nanomaterial, respectively.

In all the adsorption experiments carried out with MWCNTs, a stirring speed of $500 \mathrm{~min}^{-1}$ was used to mix the solution and the adsorbent material. By the use of aqueous solutions containing $0.01 \mathrm{~g} \mathrm{~L}^{-1} \mathrm{La}(\mathrm{III})$ at $\mathrm{pH} 6$ and carbon dosages of $4 \mathrm{~g} / \mathrm{L}$, previous experiments showed that the percentage of lanthanum uptake increased with the increase of the stirring speed from $300 \mathrm{~min}^{-1}$ (84\% metal adsorption) until reaching a maximum (99\% metal adsorption) at the above stirring speed, indicating that a minimum value of the thickness of the aqueous phase boundary layer was reached. The increase of the stirring speed to $1000 \mathrm{~min}^{-1}$ resulted in a slight decrease of the adsorption, i.e., $96 \%$ at $750 \mathrm{~min}^{-1}$ and $94 \%$ at $1000 \mathrm{~min}^{-1}$, this decrease being attributable to the formation of local equilibria at these higher stirring speeds.

The data derived from experiments at $500 \mathrm{~min}^{-1}$ were used to estimate the kinetics associated to the system, and this investigation revealed that $\mathrm{La}(\mathrm{III})$ uptake onto the present MWCNT was best represented by the pseudo-second order kinetic model $\left(r^{2}=0.989\right)$ :

$$
\frac{t}{[L a]_{c, t}}=\frac{1}{k[L a]_{c, e}^{2}}+\frac{1}{[L a]_{c, e}} t
$$

where $[L a]_{c, e}$ and $[L a]_{c, t}$ represented the lanthanum concentrations at equilibrium and at the elapsed time, respectively, $k$ represented the rate constant and $t$ the elapsed time. From this fit, it was obtained that $[\mathrm{La}]_{c, e}$ was $2.8 \mathrm{mg} / \mathrm{g}$, which fitted very well with the experimental value of $2.5 \mathrm{mg} / \mathrm{g}$, and $\mathrm{k}$ of $0.16 \mathrm{~g} \mathrm{mg}^{-1} \mathrm{~min}^{-1}$. Furthermore, the fit of the data to the pseudo-second order model should be indicative of chemical activation between the adsorbent and the lanthanum ions [35,36].

\subsubsection{Influence of the Aqueous $\mathrm{pH}$}

The influence of varying the $\mathrm{pH}$ of the aqueous solution on the adsorption of lanthanum by the MWCNTs was evaluated. Adsorbent dosages of $3 \mathrm{~g} / \mathrm{L}$ were used. The aqueous phase contained $0.01 \mathrm{~g} / \mathrm{L} \mathrm{La}(\mathrm{III})$ at various $\mathrm{pH}$ values. Table 2 shows the results obtained from these experiments. It can be seen that the decrease in the $\mathrm{pH}$ value decreased the percentage of metal adsorption onto the carbon material. This could be because the surface charge of MWCNTs turns negative at $\mathrm{pH}$ values higher than the $\mathrm{pH}$ (IEP) 1.22, see Figure 1.

Table 2. Influence of the $\mathrm{pH}$ on $\mathrm{La}(\mathrm{III})$ uptake. Temperature: $25^{\circ} \mathrm{C}$. Time: $5 \mathrm{~h}$.

\begin{tabular}{cc}
\hline $\mathbf{p H}$ & \% La(III) Uptake \\
\hline 1 & 15 \\
2 & 32 \\
3 & 61 \\
4 & 80 \\
6 & 98 \\
\hline
\end{tabular}

The results derived from experiments at $\mathrm{pH} 6$ were used to estimate the rate law for the present system, and the results derived from these fits, indicated the $\mathrm{La}(\mathrm{III})$ uptake onto the nanomaterial was best associated to the aqueous film diffusion mechanism $\left(r^{2}=0.988\right)$ :

$$
\ln (1-F)=-k t
$$

where $k$ is the rate constant, $t$ the elapsed time, and $F$ the fractional approach to the equilibrium, calculated as:

$$
F=\frac{[L a]_{c, t}}{[L a]_{c, e}}
$$


the value of $k$ being estimated as $0.03 \mathrm{~min}^{-1}$. It should be noted here, that the aqueous film diffusion was often associated to adsorption processes obeying the pseudo-second order kinetic model [37].

\subsubsection{Effect of Adsorbent Dosage}

Figure 2 represents the results obtained for the study of the influence of the adsorbent dosage on lanthanum adsorption. The aqueous solution contained $0.01 \mathrm{~g} / \mathrm{L} \mathrm{La}(\mathrm{III})$ at $\mathrm{pH} 6$ and the adsorbent dosages ranged from 1 to $4 \mathrm{~g} \mathrm{~L}^{-1}$. The results obtained showed that the increase of the adsorbent dosage increased lanthanum adsorption, however, the effectiveness of this adsorbent for metal adsorption is constant if adsorbent dosages of 3 and $4 \mathrm{~g} \mathrm{~L}^{-1}$ are used.

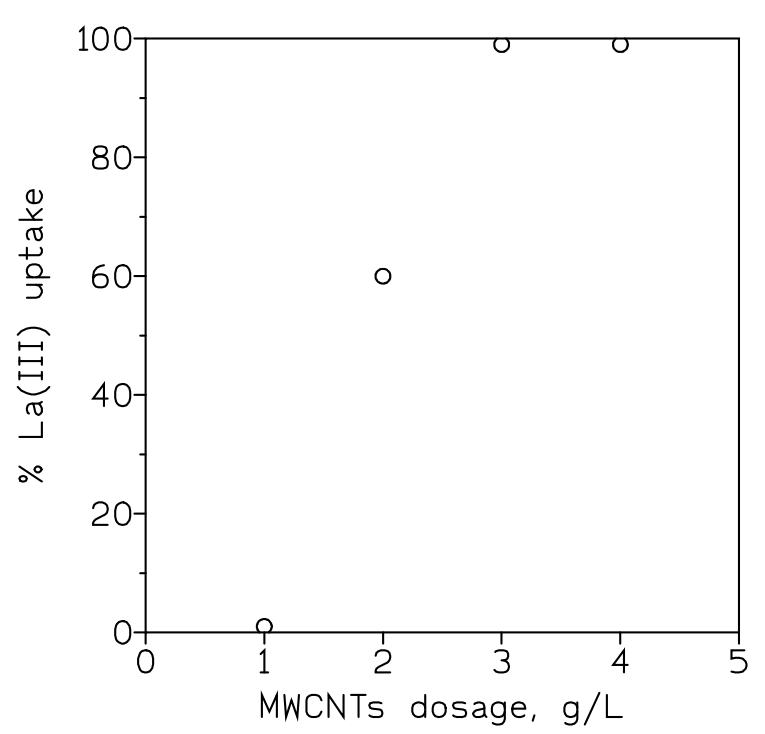

Figure 2. Influence of multiwalled carbon nanotubes (MWCNTs) dosage on the adsorption of lanthanum. Temperature: $25^{\circ} \mathrm{C}$. Time: $5 \mathrm{~h}$.

\subsubsection{Effect of Metal Concentration}

The influence of the initial lanthanum concentration on the percentage of adsorption of this metal onto the MWCNTs was investigated. This study was carried out using aqueous solutions that contained various lanthanum concentrations at pH 6 and carbon dosages of $3 \mathrm{~g} / \mathrm{L}$. The results are shown in Table 3, it can be seen that the percentage of metal adsorption decreased with the increase of the initial metal concentration in the aqueous solution, where maximum metal loading onto the nanomaterial was around $5.3 \mathrm{mg} \mathrm{g}^{-1}$.

Table 3. Influence of initial metal concentration on La(III) uptake. Temperature: $25^{\circ} \mathrm{C}$. Time: $5 \mathrm{~h}$.

\begin{tabular}{ccc}
\hline$[\mathbf{L a}]_{\mathbf{0}}, \mathbf{m g} / \mathbf{L}$ & \% La(III) Uptake & {$[\mathbf{L a}]_{\mathbf{c}, \mathbf{e}, \mathbf{~} \mathbf{~ g} / \mathbf{g}}$} \\
\hline 10 & 98 & 3.3 \\
\hline 20 & 75 & 5.0 \\
\hline 40 & 46 & 6.1 \\
\hline 80 & 20 & 5.3 \\
\hline
\end{tabular}

These results were fitted to the Langmuir and Freundlich models [38,39]; it was found that the best fit was related to the Langmuir Type-1 equation model $\left(r^{2}: 0.992\right)$, indicative of a homogeneous surface of the adsorbent covering with a single layer:

$$
\frac{[L a]_{a q, e}}{[L a]_{c, e}}=\frac{1}{k_{L}[L a]_{c, m}}+\frac{1}{[L a]_{c, m}}[L a]_{a q, e}
$$


in the above expression, $[L a]_{c, e}$ and $[L a]_{a q, e}$ represented the metal concentration in the carbon nanomaterial and in the aqueous solution at equilibrium, respectively, $[L a]_{c, m}$ is the maximum lanthanum concentration in the carbon nanomaterial, and $k_{L}$ is the Langmuir constant. From the above fit, $[L a]_{c, m}$ was $5.3 \mathrm{mg} / \mathrm{g}$, a value which compares well with the experimental value of $5.5 \mathrm{mg} / \mathrm{g}$, and $k_{L}$ being $1.4 \mathrm{~L} / \mathrm{mg}$. Moreover:

$$
R_{L}=\frac{1}{1+K_{l}[L]_{a q, 0}}
$$

it was found that in all the lanthanum concentrations range used in this work, the adsorption process is favorable since $R_{L}<1$ [40].

\subsection{La(III) Uptake by Oxidized Multiwalled Carbon Nanotubes (ox-MWCNTs)}

The presence of carboxylic groups in the carbon nanomaterial is indicative that $\mathrm{La}(\mathrm{III})$ uptake onto this nanomaterial, is not represented by an adsorption process but by a cation exchange process:

$$
3(R-\mathrm{COOH})_{c}+\mathrm{La}_{a q}^{3+} \leftrightarrow\left(R-\mathrm{COO}^{-}\right)_{3} \mathrm{Lac}_{c}^{3+}+3 \mathrm{H}_{a q}^{+}
$$

where the subscripts $c$ and $a q$ represented the equilibrated carbon and aqueous phases, respectively, and $R$ the non-reactive part of the carbon nanomaterial. As it can be seen from the above equation, $\mathrm{La}$ (III) uptake onto the oxidized nanomaterial is accompanied by the release of protons to the aqueous solution.

\subsubsection{Effect of Stirring Speed}

A number of tests were performed in order to establish correct hydrodynamic conditions. The uptake onto the carbon material was studied as a function of the stirring speed applied to the system. Results obtained are shown in Table 4, maximum lanthanum uptake for a stirring speed of $500 \mathrm{~min}^{-1}$ was obtained, thus, the thickness of the aqueous diffusion layer and the aqueous resistance to mass transfer were minimized. There was also a slight decrease in the metal uptake with the increase of the stirring speed, this effect being explained as above; however, in the present case, the stirring speed had an influence on the time to reach equilibrium, since, in the present experimental conditions, it was attained at $30 \mathrm{~min}\left(500 \mathrm{~min}^{-1}\right), 3 \mathrm{~h}\left(750 \mathrm{~min}^{-1}\right)$ and $5 \mathrm{~h}\left(1000 \mathrm{~min}^{-1}\right)$.

The estimation of the kinetic model, responsible for $\mathrm{La}(\mathrm{III})$ uptake onto the carbonaceous nanomaterial, indicated that the results at $500 \mathrm{~min}^{-1}$ best fitted to the pseudo-second order kinetic model $\left(r^{2}=0.995\right)$ Equation (3), and from this, $[L a]_{c, e}$ was of $10.9 \mathrm{mg} / \mathrm{g}$, a concentration which is a little higher than the maximum theoretical of $10 \mathrm{mg} / \mathrm{g}$, which could be derived using the present experimental conditions, and higher than the more realistic and experimentally obtained of $9.9 \mathrm{mg} / \mathrm{g}$. From this fit, and using this $9.9 \mathrm{mg} / \mathrm{g}$ value, $k$ resulted as $0.68 \mathrm{~g} / \mathrm{mg} \mathrm{min}$.

Table 4. Influence of the stirring speed on lanthanum uptake onto ox-MWCNTs. Aqueous phase: $0.01 \mathrm{~g} / \mathrm{L} \mathrm{La}(\mathrm{III})$ at $\mathrm{pH}$ 6. Carbon dosage: $1 \mathrm{~g} / \mathrm{L}$. Temperature: $25^{\circ} \mathrm{C}$. Time: $5 \mathrm{~h}$.

\begin{tabular}{cc}
\hline Stirring Speed $\left(\mathbf{m i n}^{-1}\right)$ & \% La(III) Uptake \\
\hline 250 & 70 \\
350 & 90 \\
500 & 99 \\
750 & 97 \\
1000 & 94 \\
\hline
\end{tabular}

\subsubsection{Effect of the Aqueous $\mathrm{pH}$}

Experiments were carried out using solutions of $0.01 \mathrm{~g} / \mathrm{L} \mathrm{La}(\mathrm{III})$ at various $\mathrm{pH}$ values and carbon dosages of $0.5 \mathrm{~g} / \mathrm{L}$. Figure 3 shows the results obtained. As expected from Equation (6), it can be seen 
that the variation of the aqueous $\mathrm{pH}$ value had a marked effect on $\mathrm{La}$ (III) uptake onto the ox-MWCNTs, decreasing the metal uptake as the $\mathrm{pH}$ value was decreasing. From Equation (6):

$$
K=\frac{\left[\left(R-\mathrm{COO}^{-}\right){ }_{3} \mathrm{La}^{3+}\right]\left[\mathrm{H}^{+}\right]^{3}}{[(R-\mathrm{COOH})]^{3}\left[\mathrm{La}^{3+}\right]}
$$

and by definition, the metal distribution coefficient is:

$$
D=\frac{\left[\left(R-\mathrm{COO}^{-}\right)_{3} L a^{3+}\right]}{\left[L a^{3+}\right]}
$$

substituting the above in Equation (9) and rearranging, the next expression is derived:

$$
\log D=\log [R-\mathrm{COOH}]^{3}+3 p H
$$

thus, by plotting $\log D$ versus $\mathrm{pH}$ a straight line of slope 3 may be obtained. From the results shown in Figure 3, such a plot confirming a slope of near 3, and that La(III) uptake onto these ox-MWCNTs occurred via the equilibrium shown in Equation (6). It is worth noting here, that the curve had an approximate S-shape, characteristic among others, of cationic exchangers.

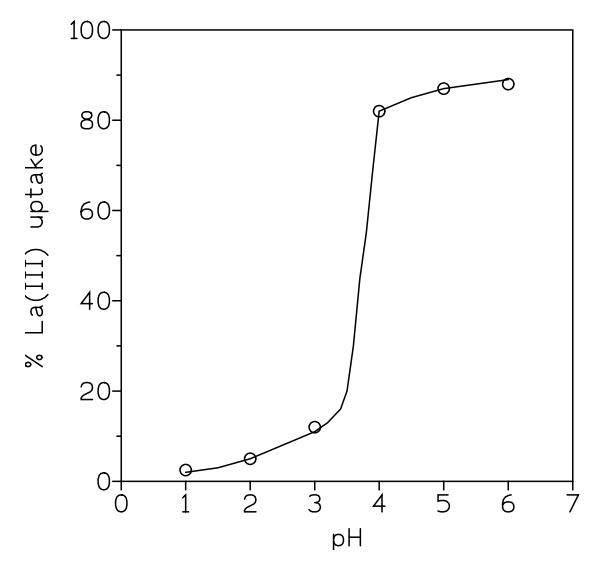

Figure 3. Variation in the percentage of $\mathrm{La}(\mathrm{III})$ adsorption versus $\mathrm{pH}$. Temperature: $25^{\circ} \mathrm{C}$. Time: $5 \mathrm{~h}$.

The results at $\mathrm{pH} 6$ were used to estimate the rate law for the lanthanum uptake onto these oxidized nanomaterials. The results fitted well with the particle diffusion model $\left(r^{2}=0.945\right)$ :

$$
\ln (1-F)^{2}=-k t
$$

and $k$ estimated as $0.06 \mathrm{~min}^{-1}$.

\subsubsection{Effect of ox-MWCNTs Dosage}

The variation in the percentage of lanthanum adsorption at different adsorbent dosages is shown in Figure 4. The experiments were carried out with carbon dosages in the 0.13 to $1 \mathrm{~g} / \mathrm{L}$ range and aqueous solutions of $0.01 \mathrm{~g} / \mathrm{L} \mathrm{La(III)} \mathrm{at} \mathrm{pH} 6$. 


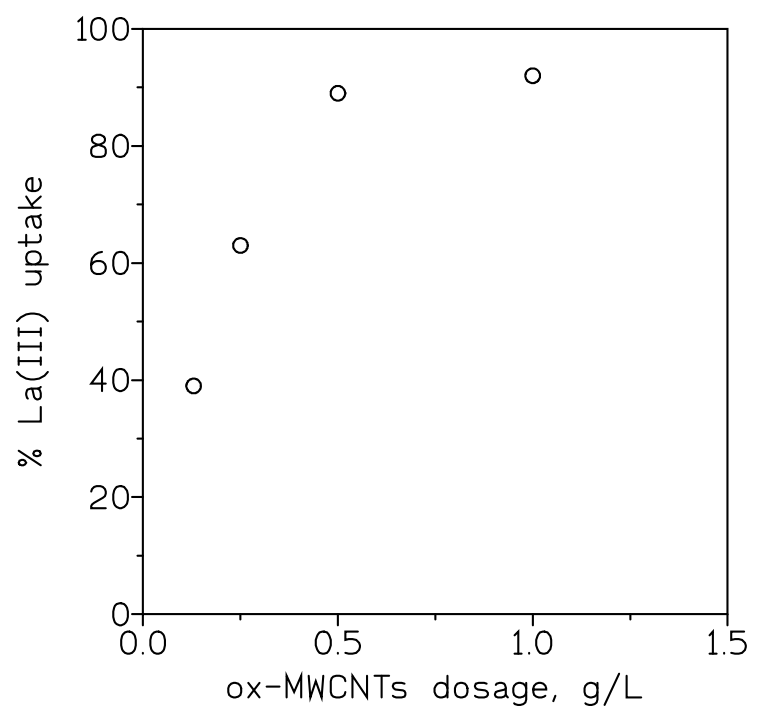

Figure 4. Influence of ox-MWCNTs dosage on the adsorption of lanthanum. Temperature: $25{ }^{\circ} \mathrm{C}$. Time: $5 \mathrm{~h}$.

The results obtained showed that increasing the adsorbent dosage increased the percentage of lanthanum adsorption from $0.5 \mathrm{~g} / \mathrm{L}$ carbon dosage, although the difference in the values is less significant than in the lower adsorbent dosage range.

\subsubsection{Effect of Initial Lanthanum Concentration}

Figure 5 shows the variation in the percentage of lanthanum uptake onto the ox-MWCNTs against the initial concentration of the metal ranging from 0.01 to $0.08 \mathrm{~g} / \mathrm{L}$. It can be observed that with the present experimental conditions, the percentage of metal uptake reached a maximum at $0.01-0.02 \mathrm{~g} / \mathrm{L}$ $\mathrm{La}(\mathrm{III})$, and then decreased.

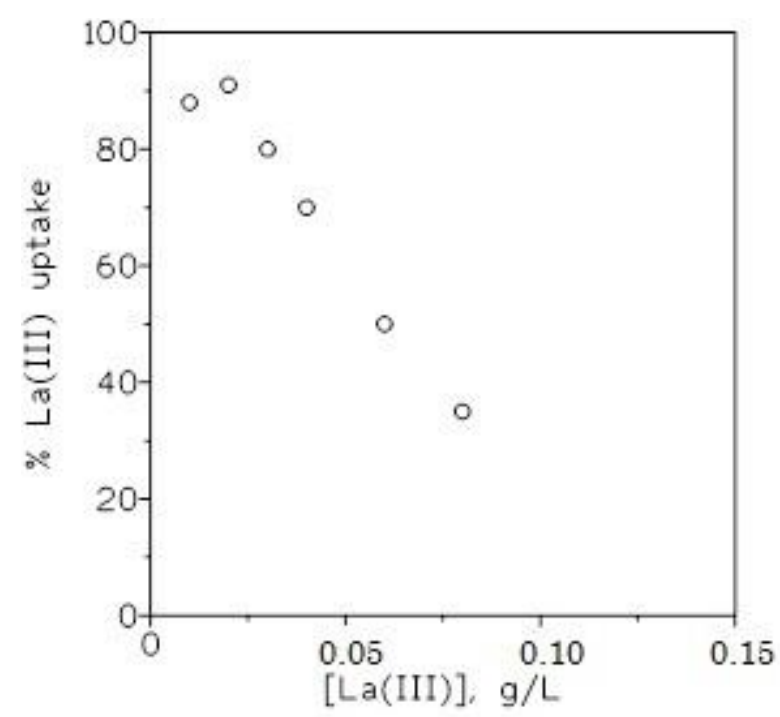

Figure 5. Influence of the initial metal concentration on the uptake of lanthanum. Aqueous phase: $\mathrm{La}(\mathrm{III})$ at $\mathrm{pH}$ 6. Adsorbent dosage: $0.5 \mathrm{~g} / \mathrm{L}$. Temperature: $25^{\circ} \mathrm{C}$. Time: $5 \mathrm{~h}$.

Lanthanum uptake is best represented by the Langmuir Type-1 isotherm (Equation (6)), with $[\mathrm{La}]_{c, m}$ of $59 \mathrm{mg} / \mathrm{g}$, a value very similar to that experimentally obtained of $57 \mathrm{mg} / \mathrm{g}$, and $k_{L} 0.78 \mathrm{~L} / \mathrm{mg}$. Considering Equation (7), the estimated value of $R_{L}$ for the system is 0.11 , indicative of a favorable metal uptake process [40]. 


\subsection{Elution}

As the results in Sections 3.1.1 and 3.2.2 show, using both adsorbents, there is a strong influence of the aqueous $\mathrm{pH}$ on lanthanum adsorption, thus, it is logical to use acidic solutions to desorb this metal from La-loaded carbon nanomaterials. This series of experiments was carried out, at $25^{\circ} \mathrm{C}$, using $0.1 \mathrm{M} \mathrm{H}_{2} \mathrm{SO}_{4}$ solutions, and an La-loaded nanomaterial in a 0.4 carbon/solution relationship. The results from these experiments showed that the percentage of lanthanum recovery in the eluate was $79 \%$ and $87 \%$ for the non-oxidized and the oxidized nanomaterials, respectively. At the same time, the nanomaterial was recovered for further use, in the case of the oxidized nanomaterial by shifting of the equilibrium shown in Equation (6) to the left, as a consequence of the desorption reaction. In the case of non-oxidized MWCNT, the use of a mild acidic solution would probably activate the adsorption sites present in the carbon matrix, without destroying this matrix, though different behavior between initial and eluted carbon material might be observed under continuous use, i.e., columns [41]. The use of $\mathrm{HCl}$ or $\mathrm{HNO}_{3}$ solutions did not improve the desorption results yielded with the use of a sulfuric acid solution.

\section{Conclusions}

From the experimental data obtained from this investigation, it can be deduced that both oxidized and non-oxidized multiwalled carbon nanotubes, commercially available materials, can be used to recover lanthanum from aqueous solutions.

For both nanomaterials, the adsorption of lanthanum, is influenced by a number of variables, such as metal concentration and adsorbent dosages, the stirring speed applied to the system, and the $\mathrm{pH}$ of the aqueous solution.

In both cases, the metal uptake corresponded to the pseudo-second order kinetic model and the Langmuir Type- 1 isotherm model, however, they differ in the rate law, as the film diffusion model fitted the uptake when the non-oxidized material is used, against the fitting of the particle diffusion model to the results yielded when the oxidized carbon nanotubes are used to remove lanthanum from the solution. The mechanism by which lanthanum is removed from the solution using both nanomaterials also appeared to be different: an adsorption process in the case of the non-oxidized carbon against a cation exchange process in the case of the oxidized material. This is somewhat reflected in the fact that to obtain the same degree of lanthanum removal from the solution (more than $90 \%$ ), the material dosage using the oxidized material is three times lower than that of the non-oxidized carbon nanotubes. Lanthanum loaded, onto both nanomaterials, can be desorbed by the use of acid solutions, e.g., sulfuric acid.

Author Contributions: Conceptualization, F.J.A. and F.A.L.; methodology, F..A. and F.A.L.; formal analysis, I.G.-D. and F.J.A.; investigation, F.J.A., F.A.L., I.G.-D., E.E.B. and O.R.L.; resources, F.A.L.; writing-original draft preparation, F.J.A.; writing-review and editing, F.J.A., F.A.L., I.G.-D., E.E.B. and O.R.L. All authors have read and agreed to the published version of the manuscript

Funding: This research has received funding from the European Union's Horizon 2020 research and innovation program under grant agreement No. 776851 (CarEService).

Acknowledgments: We acknowledge support of the publication fee by the CSIC Open Access Publication Support Initiative through its Unit of Information Resources for Research (URICI). The authors thank E. Moroño for her assistance in analytical determinations through ICP-OES.

Conflicts of Interest: The authors declare no conflict of interest.

\section{References}

1. Klinger, J.M. A historical geography of rare earth elements: From discovery to the atomic age. Extr. Ind. Soc. 2015, 2, 572-580. [CrossRef]

2. Zhou, B.; Li, Z.; Zhao, Y.; Zhang, C.; Wei, Y. Rare Earth Elements supply vs. clean energy technologies: new problems to be solve. Gospod. Surowcami Miner. 2016, 32, 29-44. [CrossRef] 
3. Goodenough, K.M.; Wall, F.; Merriman, D. The Rare Earth Elements: Demand, Global Resources, and Challenges for Resourcing Future Generations. Nat. Resour. Res. 2018, 27, 201-216. [CrossRef]

4. Jacinto, J.; Henriques, B.; Duarte, A.C.; Vale, C.; Pereira, E. Removal and recovery of Critical Rare Elements from contaminated waters by living Gracilaria gracilis. J. Hazard. Mater. 2018, 344, 531-538. [CrossRef] [PubMed]

5. EU Report on Critical Raw Materials and the Circular Economy - Publications Office of the EU. Available online: http://publications.europa.eu/resource/cellar/d1be1b43-e18f-11e8-b690-01aa75ed71a1.0001. 01/DOC_1 (accessed on 15 May 2020).

6. Omodara, L.; Pitkäaho, S.; Turpeinen, E.-M.; Saavalainen, P.; Oravisjärvi, K.; Keiski, R.L. Recycling and substitution of light rare earth elements, cerium, lanthanum, neodymium, and praseodymium from end-of-life applications-A review. J. Clean. Prod. 2019, 236, 117573. [CrossRef]

7. Jowitt, S.M.; Werner, T.T.; Weng, Z.; Mudd, G.M. Recycling of the rare earth elements. Curr. Opin. Green Sustain. Chem. 2018, 13,1-7. [CrossRef]

8. Kołodyńska, D.; Hubicki, Z.; Fila, D. Recovery of rare earth elements from acidic solutions using macroporous ion exchangers. Sep. Sci. Technol. 2019, 54, 2059-2076. [CrossRef]

9. Binnemans, K.; Jones, P.T.; Blanpain, B.; Van Gerven, T.; Yang, Y.; Walton, A.; Buchert, M. Recycling of rare earths: a critical review. J. Clean. Prod. 2013, 51, 1-22. [CrossRef]

10. Korkmaz, K.; Alemrajabi, M.; Rasmuson, Å.C.; Forsberg, K.M. Separation of valuable elements from NiMH battery leach liquor via antisolvent precipitation. Sep. Purif. Technol. 2020, 234, 115812. [CrossRef]

11. Fila, D.; Hubicki, Z.; Kołodyńska, D. Recovery of metals from waste nickel-metal hydride batteries using multifunctional Diphonix resin. Adsorption 2019, 25, 367-382. [CrossRef]

12. Innocenzi, V.; Ippolito, N.M.; De Michelis, I.; Prisciandaro, M.; Medici, F.; Vegliò, F. A review of the processes and lab-scale techniques for the treatment of spent rechargeable NiMH batteries. J. Power Sources 2017, 362, 202-218. [CrossRef]

13. Ueberschaar, M.; Geiping, J.; Zamzow, M.; Flamme, S.; Rotter, V.S. Assessment of element-specific recycling efficiency in WEEE pre-processing. Resour. Conserv. Recycl. 2017, 124, 25-41. [CrossRef]

14. García-Díaz, I.; López, F.; Alguacil, F. Carbon Nanofibers: A New Adsorbent for Copper Removal from Wastewater. Metals (Basel) 2018, 8, 914. [CrossRef]

15. Zhang, H.; Tangparitkul, S.; Hendry, B.; Harper, J.; Kim, Y.K.; Hunter, T.N.; Lee, J.W.; Harbottle, D. Selective separation of cesium contaminated clays from pristine clays by flotation. Chem. Eng. J. 2019, 355, 797-804. [CrossRef]

16. Danyliuk, N.; Tomaszewska, J.; Tatarchuk, T. Halloysite nanotubes and halloysite-based composites for environmental and biomedical applications. J. Mol. Liq. 2020, 309, 113077. [CrossRef]

17. Haldar, D.; Duarah, P.; Purkait, M.K. MOFs for the treatment of arsenic, fluoride and iron contaminated drinking water: A review. Chemosphere 2020, 251, 126388. [CrossRef]

18. Nuithitikul, K.; Phromrak, R.; Saengngoen, W. Utilization of chemically treated cashew-nut shell as potential adsorbent for removal of $\mathrm{Pb}(\mathrm{II})$ ions from aqueous solution. Sci. Rep. 2020, 10, 3343. [CrossRef]

19. Dutta, S.; Manna, K.; Srivastava, S.K.; Gupta, A.K.; Yadav, M.K. Hollow Polyaniline Microsphere $/ \mathrm{Fe}_{3} \mathrm{O}_{4}$ Nanocomposite as an Effective Adsorbent for Removal of Arsenic from Water. Sci. Rep. 2020, 10, 4982. [CrossRef]

20. Lapo, B.; Bou, J.J.; Hoyo, J.; Carrillo, M.; Peña, K.; Tzanov, T.; Sastre, A.M. A potential lignocellulosic biomass based on banana waste for critical rare earths recovery from aqueous solutions. Environ. Pollut. 2020, 264, 114409. [CrossRef]

21. Renu; Agarwal, M.; Singh, K. Heavy metal removal from wastewater using various adsorbents: a review. J. Water Reuse Desalin. 2017, 7, 387-419. [CrossRef]

22. Alcaraz, L.; Escudero, M.E.; Alguacil, F.J.; Llorente, I.; Urbieta, A.; Fernández, P.; López, F.A. Dysprosium Removal from Water Using Active Carbons Obtained from Spent Coffee Ground. Nanomaterials 2019, 9, 1372. [CrossRef] [PubMed]

23. Lu, F.; Astruc, D. Nanomaterials for removal of toxic elements from water. Coord. Chem. Rev. 2018, 356, 147-164. [CrossRef]

24. Liu, H.; Qiu, H. Recent advances of 3D graphene-based adsorbents for sample preparation of water pollutants: A review. Chem. Eng. J. 2020, 393, 124691. [CrossRef] 
25. Vilardi, G.; Mpouras, T.; Dermatas, D.; Verdone, N.; Polydera, A.; Di Palma, L. Nanomaterials application for heavy metals recovery from polluted water: The combination of nano zero-valent iron and carbon nanotubes. Competitive adsorption non-linear modeling. Chemosphere 2018, 201, 716-729. [CrossRef]

26. Alguacil, F.J.; López, F.A. On the Active Adsorption of Chromium(III) from Alkaline Solutions Using Multiwalled Carbon Nanotubes. Appl. Sci. 2019, 10, 36. [CrossRef]

27. Alguacil, F. Adsorption of Gold(I) and Gold(III) Using Multiwalled Carbon Nanotubes. Appl. Sci. 2018, 8, 2264. [CrossRef]

28. Alguacil, F.J.; Lopez, F.A.; Garcia-Diaz, I. Extracting metals from aqueous solutions using Ti-based nanostructures: A review. Desalin. Water Treat. 2016, 57, 17603-17615. [CrossRef]

29. Crane, R.A.; Sapsford, D.J. Sorption and fractionation of rare earth element ions onto nanoscale zerovalent iron particles. Chem. Eng. J. 2018, 345, 126-137. [CrossRef]

30. Zhao, F.; Yang, Z.; Wei, Z.; Spinney, R.; Sillanpää, M.; Tang, J.; Tam, M.; Xiao, R. Polyethylenimine-modified chitosan materials for the recovery of $\mathrm{La}(\mathrm{III})$ from leachates of bauxite residue. Chem. Eng. J. 2020, 388, 124307. [CrossRef]

31. Iftekhar, S.; Ramasamy, D.L.; Srivastava, V.; Asif, M.B.; Sillanpää, M. Understanding the factors affecting the adsorption of Lanthanum using different adsorbents: A critical review. Chemosphere 2018, 204, 413-430. [CrossRef]

32. Oral, A.E.; Aytas, S.; Yusan, S.; Sert, S.; Gok, C.; Elmastas Gultekin, O. Preparation and Characterization of a Graphene-Based Magnetic Nanocomposite for the Adsorption of Lanthanum Ions from Aqueous Solution. Anal. Lett. 2020, 53, 1812-1833. [CrossRef]

33. Liao, Q.; Zou, D.; Pan, W.; Linghu, W.; Shen, R.; Li, X.; Asiri, A.M.; Alamry, K.A.; Sheng, G.; Zhan, L.; et al. Highly efficient capture of $\mathrm{Eu}(\mathrm{III}), \mathrm{La}(\mathrm{III}), \mathrm{Nd}(\mathrm{III}), \mathrm{Th}(\mathrm{IV})$ from aqueous solutions using g-C3N4 nanosheets. J. Mol. Liq. 2018, 252, 351-361. [CrossRef]

34. Cardoso, C.E.D.; Almeida, J.C.; Lopes, C.B.; Trindade, T.; Vale, C.; Pereira, E. Recovery of Rare Earth Elements by Carbon-Based Nanomaterials-A Review. Nanomaterials 2019, 9, 814. [CrossRef] [PubMed]

35. Bayazit, G.; Tartan, B.E.; Güi, Ü. Biosorption, isotherm and kinetic properties of common textile dye by phormidium animale. Glob. NEST J. 2019. [CrossRef]

36. Amin, M.T.; Alazba, A.A.; Manzoor, U. A Review of Removal of Pollutants from Water/Wastewater Using Different Types of Nanomaterials. Adv. Mater. Sci. Eng. 2014, 2014, 1-24. [CrossRef]

37. Hubbe, M.A.; Azizian, S.; Douven, S. Implications of Apparent Pseudo-Second-Order Adsorption Kinetics onto Cellulosic Materials: A Review. Bioresources 2019, 14, 7582-7626.

38. Langmuir, I. The adsorption of gases on plane surfaces glass, mica and platinum. J. Am. Chem. Soc. 1918, 40, 1361-1403. [CrossRef]

39. Freundlich, H. Über die Adsorption in Lösungen. Z. Phys. Chem. 1907, 57U. [CrossRef]

40. Foo, K.Y.; Hameed, B.H. Insights into the modeling of adsorption isotherm systems. Chem. Eng. J. 2010, 156, 2-10. [CrossRef]

41. Ippolito, N.M.; Maffei, G.; Medici, F.; Piga, L. Adsorption and regeneration of fluoride ion on a high alumina content bauxite. Chem. Eng. Trans. 2016, 47, 217-222. [CrossRef]

(C) 2020 by the authors. Licensee MDPI, Basel, Switzerland. This article is an open access article distributed under the terms and conditions of the Creative Commons Attribution (CC BY) license (http://creativecommons.org/licenses/by/4.0/). 